\title{
Front Matter: Volume 9581
}

, "Front Matter: Volume 9581," Proc. SPIE 9581, Laser Beam Shaping XVI, 958101 (16 September 2015); doi: 10.1117/12.2208535

SPIE Event: SPIE Optical Engineering + Applications, 2015, San Diego, California, SPIE. United States 


\title{
PROCEEDINGS OF SPIE
}

\section{Laser Beam Shaping XVI}

\author{
Andrew Forbes \\ Todd E. Lizotte \\ Editors
}

10 August 2015

San Diego, California, United States

Sponsored and Published by

SPIE 
The papers in this volume were part of the technical conference cited on the cover and title page. Papers were selected and subject to review by the editors and conference program committee. Some conference presentations may not be available for publication. Additional papers and presentation recordings may be available online in the SPIE Digital Library at SPIEDigitallibrary.org.

The papers reflect the work and thoughts of the authors and are published herein as submitted. The publisher is not responsible for the validity of the information or for any outcomes resulting from reliance thereon.

Please use the following format to cite material from this proceedings:

Author(s), "Title of Paper," in Laser Beam Shaping XVI, edited by Andrew Forbes, Todd E. Lizotte, Proceedings of SPIE Vol. 9581 (SPIE, Bellingham, WA, 2015) Six-digit Article CID Number.

ISSN: 0277-786X

ISSN:1996-756X (electronic)

ISBN: 9781628417470

Published by

SPIE

P.O. Box 10, Bellingham, Washington 98227-0010 USA

Telephone +1 3606763290 (Pacific Time) · Fax +1 3606471445

SPIE.org

Copyright (C) 2015, Society of Photo-Optical Instrumentation Engineers.

Copying of material in this book for internal or personal use, or for the internal or personal use of specific clients, beyond the fair use provisions granted by the U.S. Copyright Law is authorized by SPIE subject to payment of copying fees. The Transactional Reporting Service base fee for this volume is $\$ 18.00$ per article (or portion thereof), which should be paid directly to the Copyright Clearance Center (CCC), 222 Rosewood Drive, Danvers, MA 01923. Payment may also be made electronically through CCC Online at copyright.com. Other copying for republication, resale, advertising or promotion, or any form of systematic or multiple reproduction of any material in this book is prohibited except with permission in writing from the publisher. The CCC fee code is 0277-786X/15/\$18.00.

Printed in the United States of America.

Publication of record for individual papers is online in the SPIE Digital Library.

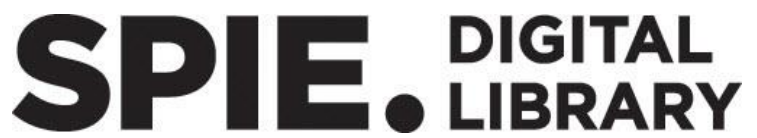

SPIEDigitalLibrary.org

Paper Numbering: Proceedings of SPIE follow an e-First publication model. A unique citation identifier (CID) number is assigned to each article at the time of publication. Utilization of CIDs allows articles to be fully citable as soon as they are published online, and connects the same identifier to all online and print versions of the publication. SPIE uses a six-digit CID article numbering system structured as follows:

- The first four digits correspond to the SPIE volume number.

- The last two digits indicate publication order within the volume using a Base 36 numbering

system employing both numerals and letters. These two-number sets start with $00,01,02,03,04$, 05, 06, 07, 08, 09, 0A, OB ... 0Z, followed by 10-1Z, 20-2Z, etc. The CID Number appears on each page of the manuscript. 


\title{
Contents
}

\author{
$\checkmark$ Authors \\ vii Conference Committee
}

\section{SESSION 1 LASER BEAMS}

958104 Angular accelerating white light [9581-2]

958105 Self-healing of Hermite-Gauss and Ince-Gauss beams [9581-3]

958106 Classical entanglement of vector vortex beams [9581-4]

\section{SESSION 2 LASERS AND RESONATORS}

$9581 \mathrm{OB}$ Selective excitation and detection of higher-order doughnut laser modes as an incoherent superposition of two petals modes in a digital laser resonator [9581-9]

\section{SESSION 3 TECHNIQUES I}

9581 OC C-shaped electron beams: design, experimental production and application [9581-10]

$9581 \mathrm{OE} \quad$ Electronically controlled optical tweezing using space-time-wavelength mapping [9581-12]

9581 OF Encoding information using Laguerre Gaussian modes [9581-13]

\section{SESSION 4 TECHNIQUES II}

$95810 G$ Experimental generation of Hermite-Gauss and Ince-Gauss beams through kinoform phase holograms [9581-14]

$9581 \mathrm{OH} \quad$ New approach for laser beam formation by means of deformable mirrors [9581-15]

9581 OK Square shaped flat-top beam in refractive beam shapers [9581-18]

9581 OL Beam shaping concepts with aspheric surfaces [9581-19]

\section{POSTER SESSION}

9581 ON High order vortex beam in the optical vortex microscope [9581-21] 
9581 OP Practical considerations of producing propagation invariant laser beams [9581-23]

$95810 Q \quad$ Fabrication and characterization of a non-zero dispersion-shifted mechanically-induced long-period grating for optical fiber sensing [9581-24]

9581 OS Low-loss selective excitation of higher-order modes in a diode-pumped solid state digital laser [9581-26] 


\section{Authors}

Numbers in the index correspond to the last two digits of the six-digit citation identifier (CID) article numbering system used in Proceedings of SPIE. The first four digits reflect the volume number. Base 36 numbering is employed for the last two digits and indicates the order of articles within the volume. Numbers start with 00, 01, 02, 03, 04, 05, 06, 07, 08, 09, 0A, 0B...0Z, followed by 10-1Z, 20-2Z, etc.

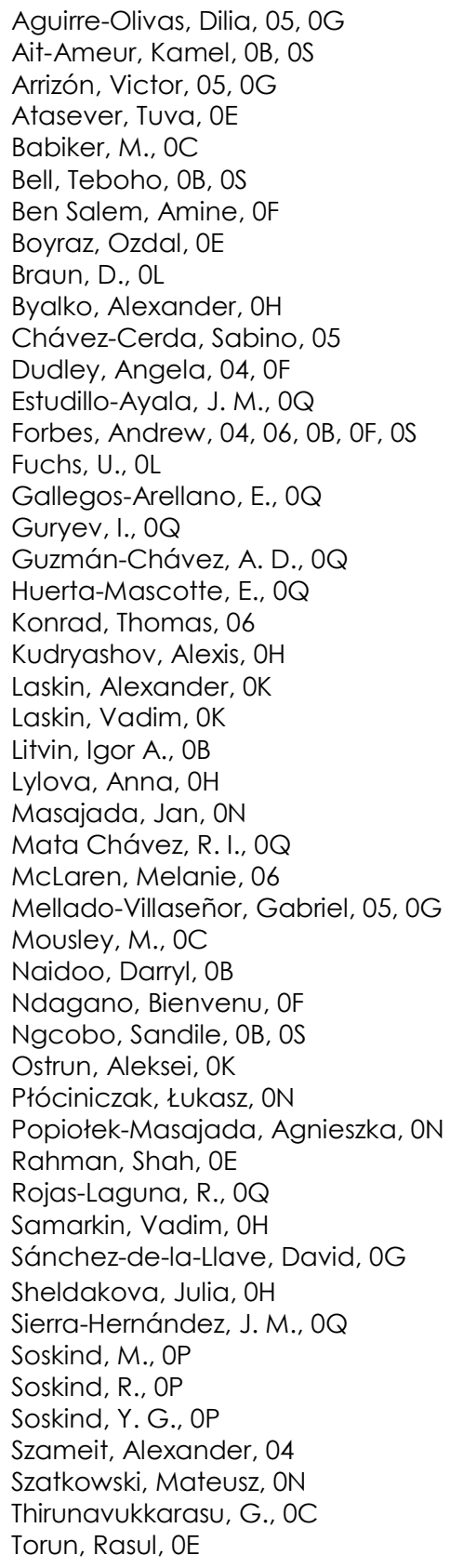

Trichili, Abderrahmen, OF

Vargas-Rodriguez, E., OQ

Vetter, Christian, 04

Wickenhagen, S., OL

Yuan, J., OC

Zghal, Mourad, OF

Zhao, Qiancheng, OE 
Proc. of SPIE Vol. $9581958101-6$

Downloaded From: https://www.spiedigitallibrary.org/conference-proceedings-of-spie on 26 Apr 2023 Terms of Use: https://www.spiedigitallibrary.org/terms-of-use 


\section{Conference Committee}

Program Track Chairs

José Sasián, College of Optical Sciences, The University of Arizona (United States)

R. John Koshel, College of Optical Sciences, The University of Arizona (United States)

Conference Chairs

Andrew Forbes, University of the Witwatersrand (South Africa) and CSIR National Laser Center (South Africa)

Todd E. Lizotte, Hitachi Via Mechanics (USA), Inc. (United States)

Conference Program Committee

Daniel M. Brown, Optosensors Technology, Inc. (United States)

Fred M. Dickey, FMD Consulting LLC (United States)

Angela Dudley, CSIR National Laser Center (South Africa)

Michael Duparré, Friedrich-Schiller-Universität Jena (Germany)

Julio Cesar Gutiérrez-Vega, Tecnológico de Monterrey (Mexico)

Marc D. Himel, JENOPTIK Optical Systems GmbH (Germany)

Alexander V. Laskin, AdlOptica Optical Systems GmbH (Germany)

Alexis V. Kudryashov, Active Optics Night N Ltd. (Russian Federation)

Carlos López-Mariscal, U.S. Naval Research Laboratory

(United States)

David L. Shealy, The University of Alabama at Birmingham

(United States)

Yakov G. Soskind, DHPC Technologies (United States)

Session Chairs

1 Laser Beams

Fred M. Dickey, FMD Consulting LLC (United States)

2 Lasers and Resonators

Yakov G. Soskind, DHPC Technologies (United States)

3 Techniques I

Alexander V. Laskin, AdlOptica Optical Systems GmbH (Germany)

4 Techniques II

Angela Dudley, CSIR National Laser Center (South Africa) 
Proc. of SPIE Vol. $9581958101-8$

Downloaded From: https://www.spiedigitallibrary.org/conference-proceedings-of-spie on 26 Apr 2023 Terms of Use: https://www.spiedigitallibrary.org/terms-of-use 